\title{
The Challenges of Teaching English during the Outbreak of COVID-19
}

\author{
Dušica Karimanović
}

\section{ABSTRACT}

Coping with the new "normalities" itself was difficult a task to undergo, let alone creating a positive-enforced surrounding for young minds to flourish and develop. Teaching as a profession has gone through so many changes in such a short time that it is almost impossible to tackle all of them in one article. Be that as it may, the following one represents both a recollection of challenges that teaching English had to face and a collection of practices that might be of use to all of the teachers trying to teach English in versatile environments. We will discuss the differences of teaching English online in primary schools in towns, villages as well as schools for the disabled. Furthermore, we will take a look at the accessibility of tools, networks, equipment and competence of using it in each environment separately. Finally, we will state the benefits and drawbacks of teaching English online in these environments and state the examples of good practices and language skills that can be improved in all the target groups mentioned. This article does not offer a solution to the problems of teaching English in a challenging environment, but it could be a stepping stone to implementing some vital changes to a school curriculum and adapting them to the needs of an individual learner.

Keywords: COVID-19, foreign language, remote learning, teaching English online.

\section{INTRODUCTION}

The outbreak of COVID-19 in the world has massively influenced how we had perceived life and being alive, let alone the drivers of human society. Teachers are by far one of the prime drivers in education, and these changes were felt by every individual, be it directly or indirectly. Serbia announced a complete lockdown in the second half of March 2020. The schools were closed and students sent home. But the prime question for the whole educational system of the country was: What to do now? and How?

Teachers didn't find this idea of online teaching completely new. For the past decade the Ministry of Education, Science and Technological Development has been organizing numerous conferences, seminars and workshops to introduce e-learning and teaching methods to our classrooms. For the time being, we were given the freedom of choice in terms of opting for a suitable tool to hold on to complete the 2019/20 school year with minimum negative consequences, bearing in mind the physical and psychological well-being of our students.

The 2020/21 school year was followed by an introduction of a single platform, depending on a school, and to a far extent unified teaching practice at the time. It was a stepping stone for remote learning country-wide and offered a school-like environment to both students and teachers. Even though the
Published Online: October 04, 2021

ISSN: $2736-4534$

DOI : $10.24018 /$ ejedu.2021.2.5.172

D. Karimanović*

School for the Deaf "Miodrag V. Matić",

Užice, Serbia.

(e-mail: dkarimanovic@gmail.com)

*Corresponding Author input obtained by the school was identical at first glance, each subject and teacher had a unique practice that diversified and multi-layered the output. This had a large benefit to all of us since we were able to learn from each other's experiences without wasting precious time taking up more seminars. Another question we needed to tackle was the amount of curriculum we could cover teaching solely online. In one of the reports on current practice, the Ministry highlighted that we shouldn't omit more than $20 \%$ of the planned. Again, we had the freedom to choose what would be obsolete, which was a rather sensitive issue.

What teachers of English have already learnt from the short 2019/20 online school practice was that our students have changed. We weren't dealing with passive recipients anymore because "today's students are no longer the people our educational system was designed to teach" [1]. We had to deal with "digital natives" that no books or university professors could have prepared us for. On the other hand, the teachers here could only be perceived as "digital immigrants" being less capable of handling computer literacy than their students.

Foreign language teachers needed to combine approaches and study new learning methods to motivate pupils. Some of the methods that stood out were "active learning based on experience" and "co-design of learning experiences personalized to individual needs and preferences" [2]. In a way, active learning has been predominantly practised with 
younger students at the beginning of schooling, though for remote learning, it needed to be widely used to retain students' attention and motivation. As far as personalization is concerned, it has never left the classrooms for a single moment, because this is what language teachers do daily adapt and overcome problems together with their students while being aware of their specific needs.

Numerous individualities are encompassed in remote learning and teaching: individual country, individual school, individual subject, individual teacher, individual student... These are followed by distinct areas to cover, aims to reach, and minds to ignite. So how do we choose the right tool? The tool itself should be of secondary importance. Technology has provided us with infinite benefits to education, but let us not forget pedagogy as our prime task. Since we are at the rise of a new era in education, our aims should be student-centred. They should be shaping our newly adopted teaching practice because they are the spark we need for ignition and what will make that era successful.

There are plenty of manners in which we could conduct a lesson: face-to-face, recorded lessons, video materials, questionnaires, virtual simulations [3]. Based on the research from the ECAR Study of Undergraduate Students and Information Technology 2019 , "about $70 \%$ of students favour mostly or completely face-to-face learning environments" [4]. This allows us to presume that a blended method of teaching would be the most appropriate one to apply. Simultaneous sharing ideas, connecting materials and experiences with their peers and teachers provide students with a prosperous environment suitable for flourishing. Some of the stated benefits were increased flexibility, multimedia integration, as well as ease of access [5].

\section{REMOTE TEACHING AND LEARNING ENGLISH}

All of these global changes have largely influenced English language practice. Being a link between local and global experiences, knowledge and heritage, the methodology of teaching a language has always been a fertile ground for innovation and technologies. After all, English is the language of IT and computing, so it should not be considered a surprise that most of those teachers embraced new teaching methods. They were also frequently consulted about new tools on the part of their colleagues. Once again, mutual collaboration and language knowledge were confirmed to be the best recipe for success.

What's adding complexity to the manner of organising and conducting online classes of English is the fact that there are several categories of students in various conditions onto which the teaching model should be applied. Hence, the article will focus on teaching the English language in three different environments: primary town school, primary village school and primary regional school for the disabled. The parameters we would like to discuss are class size and diversity, equipment and tools used, students' motivation and productivity during classes of English. The schools were largely under the combined model of teaching - 30 minutes of direct in-school practice followed by a 15-minute practice via an online platform. For this article, we will solely focus on the remote type of teaching during a complete lockdown, which lasted 45 minutes, as long as a regular school class.

\section{TEACHING ENGLISH IN PRIMARY TOWN SCHOOL}

Town school classes consisted of up to 30 students so the diversity was at its finest. At least half of the students were attending lessons actively and didn't experience major problems in terms of technology, platform or signal strength. Most of them used mobile phones as their basic means of connection, which affected some tasks with multimedia materials. Of course, not everything was spick and span. Due to limited time for preparation and rapid changes from inschool to remote teaching, lots of teachers were disoriented [6]. Teachers struggled not to lose their target or over an experiment in such a versatile environment. We tried to stick to some tools and practices that turned out beneficial and switched from one to the other whenever we would sense that students became dormant.

The classes were conducted on the Google Classroom platform, largely by blending live communication via Meet with some other tools to enhance their activity and motivation, such as presentations, questionnaires, videos, pictures, listening and reading materials. The atmosphere during classes was usually lively. We would spark a conversation either by some current topics of their interest, or use topics related to their lessons adapting them to their own experience. Multimedia materials helped to a great extent and boosted the overall class quality.

For some of the students, this environment helped to overcome a lack of confidence and speak up, whereas for the others it was not so challenging. There was a small number of students who decided to be completely inactive stating technical, signal or health issues as their "cloak of invisibility" [7] excusing themselves from classes. An even smaller number of town school students were eager to attend both regular and additional classes, which resulted in three of them being willing to take part in a local and regional competition, two of them reaching the national level among 100 finest in Serbia.

Productivity in such a challenging environment led the teachers of English to follow the old designer proverb that "less is more" [8]. We agreed not to give students extensive homework, rather some simple tasks that weren't so timeconsuming because students "complained of heavy workloads and fatigue" [9] from spending so much time before computers. Some of them even admitted being too tired for gaming. Whenever we would try our luck with some short essays or presentations done on our part, not that many pieces of homework would be submitted, even with a flexible deadline.

Students excelled in speaking and listening skills. It was exceptionally important for all of us that they were finally able to hear English language teachers without a face mask and that we could improve their pronunciation as well. They loved short online exercises for practising vocabulary and grammar with self-check. They became more independent and started using online tools with greater interest, boosting intrinsic motivation and confidence. We noticed they opened up about unfamiliar language points, started asking more questions, firstly through private messages and emails and later on in comments and even posts on the Stream page.

Less productivity was visible in reading and writing tasks, as well as projects and presentations. Students complained that they were time-consuming or that they did not understand 
the task itself. In these situations we had to refrain from a discussion, thus speaking and listening skill development.

In a nutshell, remote teaching in a town school can be a success, though it heavily relies on technical support and computer literacy. Similar findings were represented in some Latin American countries last year [10].

\section{Teaching English in PRIMARY VILlage SCHOOL}

When primary village schools are in question, the common size usually does not exceed 10 pupils per class. The issues concerning rural areas are technological and network accessibility, which was the dominant idea of conducting lessons during pandemics. Most of the students in rural areas had some means of technology, mainly their mobile phones, though the connection strength was often poor. A report on education during COVID-19 stated that "unequal access to online learning opportunities widens pre-existing gaps in access to information and knowledge, hindering socialization and inclusion in general, not to mention the learning process that distance education seeks to provide" [11].

Mountainous terrain and remoteness of the village at times made it difficult to conduct classes of English in a rural environment completely online, so we would hold up to 20 minutes of a face-to-face class, trying to cover the most important ideas or further explain something the pupils did not understand. Most of them had a hard time learning to use the platform itself (Google Classroom as well) or checking their emails duly, but after they got the hold of it classes continued more smoothly. All of them were thrilled to learn in this way because they didn't have to get up early to travel to school and it was fun for them to be able to communicate with their English teachers online.

It goes without saying that "curriculum writers, with all good intentions, have compiled volumes of well-conceived educational action plans, choosing specific materials and activities for their pre-conceived target, curriculum receivers, students, only to find that the curriculum users, teachers, are not prepared for the innovations" [12]. Thinking outside the box during a teaching in these unprecedented times was vital since the common curriculum was inapplicable, students lacked language knowledge, skills, equipment, and stable connection.

We needed to overcome initial online learning barriers and discover how to use online tools for language practice. This meant that we extensively used the option of screen sharing, going step by step and thoroughly explaining each learning application or tool. The kids welcomed new practices with joy and amusement finding this manner of learning playful. They didn't mind doing the same exercises over and over again, just for the sake of fun. Slowly it built their confidence, so we chose not to vary tools too much. At this point we needed them to know what to do with new vocabulary, how to use a monolingual online dictionary by themselves and check pronunciation, how to search for additional self-check exercises and assure them it was preferable to contact their teachers of English whenever they had any questions. Due to limited connection, they had the opportunity to contact us on our private phones, had more flexible deadlines and all of the notes posted by us weekly, to have access whenever the connection was stable. The same audio/visual content was sent to them via Viber class groups since this application rendered the media size requiring less data, thus reaching students faster. After all, "inclusive education is a child's right, not a privilege" [12], and they shouldn't be deprived of basic means of education conduction, irrelevant to the COVID-19 crisis.

Learning language during pandemics also had some benefits in rural areas. Unlike town school pupils, they were improving both reading and writing skills, as well as pronunciation. They loved recording themselves reading parts or whole textbook materials, frequently updating their teachers with audio clips asking them to correct them and note their progress. They were willing not just to send a picture of their reading task, but the corrected version as well. Sometimes they would ask for permission to complete a whole page in their workbook, even though we did not feel comfortable piling them with multiple exercises. We were afraid they would lose interest soon or become too exhausted, so we supported their ambition, but didn't make it obligatory for the whole class.

Overall, students enjoyed remote learning, treasuring activities and skills that offered them more thinking time, not making too much progress with speaking, though.

\section{TEACHING ENGLiSh In Primary REgIONAL SCHOOL FOR THE DISABLED}

Disabled students are an integral part of our society, so they must not be omitted from the national curriculum and need to continue receiving "support and general education services together with their peers according to an Individualized Education Program (IEP) in the least restrictive educational environment - general education classes" [13]. Regrettably, this was barely possible due to the swiftness and complexity of the changes, so their improvement was "under a serious risk" [14].

Disabled students do not like changes, so transferring to remote teaching caused additional trauma. They are fond of human contact and bonding, ask for your undivided attention and physical presence while learning the language. The "lack of school and work-life during the quarantine naturally causes a change in daily routines" [13] and influences students' wellbeing. When all of this is abruptly taken away, what's left on both sides is the state of shock and a huge void. Unfortunately, the system did not have a solution to this problem, so the schools and teachers were left on a deserted island with all the freedom in language practice they could get. It did not serve for much, though.

After seeking help on many levels and knocking on the doors of many institutions without any ready solutions, we needed to compose ourselves and set priorities wisely. Decisions had to be such as to cause minimal disturbance to child's mental safety and parents' daily activities, yet having some educational purpose, or at least maintaining the child's current level of language knowledge. Following international practice and common sense, we knew we needed to get in contact with each parent, sometimes both of them in case of split families, and try to work out how we would be able to conduct lessons in English [15]. An online platform was of no use since plenty of parents did not have either the required equipment or the connection. Lots of them were unable to 
help in the process because they did not know any English themselves or we couldn't find an appropriate way to get any suitable feedback that we could rely on for estimation of progress and further planning.

We agreed to rely heavily on our students' previous knowledge and started revising the language units we have covered together in school. In cases where parents had the necessary equipment and offered enough feedback, we would dare to introduce some new language points. Yet, where this was impossible, we would call the students by landline phone, sing the songs, play some tunes they liked, check and refresh their memory until they would lose focus or send them worksheets with thorough explanations via post office hoping it would reach them (at times it took two weeks). This way we hoped to have covered the active and passive language teaching approach, though none of the worksheets has ever been brought back, so regrettably, we have no update on how helpful they were.

With young learners, the improvement during remote teaching was slower, though they were able to quickly cover what we had left out when they came back to school. Mature students had more progress, though they have more developed motor skills. Their parents are also used to technologies to a larger extent, so they had a better starting point, whatsoever. Some of the disabled students are of delicate health, which means in the past, before pandemics, we conducted remote lessons in a similar manner. Of course, teaching English to an individual for a set amount of time is one thing and cannot be compared to teaching English to many disabled individuals simultaneously for an unknown period.

English language practice with these children differs largely from the practice regular schools since all of the materials used need to be adapted to child's specific needs [16] The prime idea of English classes is to let our students know they are safe and that they are not alone. With youngsters we should try to improve listening skills and pronunciation, so using plenty of songs that children love because lots of them share music background with some Serbian songs is the key to creating a fertile environment where they are ready to soak knowledge and positive energy. During online classes, older students can improve their writing skills, sentence structure, and boost vocabulary, though we should be careful not to burden them. They enjoy online vocabulary and unscramble games, short cartoons with English subtitles and quizzes. Their attention span is usually shorter, so we should keep things simple and quick.

Online education with the disabled is a field that is still developing, especially when it comes to learning a language. The students and parents have been challenged in so many different ways that a unique solution is almost impossible to find. Thus, each progress you make with them during remote learning is a huge and rewarding victory.

\section{CONCLUSION}

By now we have all realized that Covid-19 is here to stay and, as educators, we need to be ready to cope with all obstacles that keep emerging. Also, "education system managers must be aware of their teachers' ability levels and must set expectations accordingly" [17]. Without mutual collaboration, setting priorities and maintaining flexibility, the system will not be able to function, which means that the curriculums and standards will not be met and, what's worse, students will lose motivation. Without them, the system simply does not exist.

The majority of language teaching methods educators were advised to implement comprised platforms and tools aiming at students with competent equipment and computer literacy but "within situational reports and the results of studies, many children are reported not to carry out distance education properly because they are deprived of computer or Internet access due to financial insufficiencies in the world" [18]. Moreover, "very few students with special needs received support or most of them were not supported at all during the COVID-19 pandemic process" [19].

These findings leave us with many questions but are also providing a plethora of various ideas for the coming school year. Teachers of English should include experiences stemming from students, parents and, of course, other teachers and intertwine them with the best practices and curriculum priorities adapting it and shaping it into something that could serve as a possible model of a new age in language teaching. It will be far from perfect, but the goal should be unique - creating capable young people confident in exploring and learning a language in any life context.

\section{REFERENCES}

[1] M. Prensky, "Digital Natives, Digital Immigrants Part 1," On the Horizon, vol. 9, no. 5, pp. 1-6, 2001. Available: https://doi.org/10.1108/10748120110424816

[2] C. Dede, "Planning for Neo millennial Learning Styles," Educ. Q., vol. 28, pp. 7-12, January 2005. Available: https://er.educause.edu/articles/2005/1/planning-for-neomillenniallearning-styles

[3] A. Norton, J. Sonnemann, C. McGannon, "The Online Evolution When Technology Meets Tradition in Higher Education," Grattan Institute: Melbourne, Australia. pp. 21, April 2013.

[4] D.C. Gierdowski, (October 2019). "ECAR Study of Undergraduate Students and Information Technology. " ECAR: Louisville, CO, USA, pp. 3. [Online]. Available: https://library.educause.edu//media/files/library/2019/10/studentstudy2019.pdf?la=en \&hash=25F BB396AE482FAC3B765862BA6B197DBC98B42C.

[5] B. Alexander, K. Ashford-Rowe, N. Barajas-Murphy, G. Dobbin, J. Knott, M. McCormack, J. Pomerantz, R. Seilhamer, N. Weber, (2019). EDUCAUSE Horizon Report: 2019 Higher Education Edition. EDUCAUSE: Louisville, CO, USA. pp. 21. [Online]. Available: https://library.educause.edu//media/files/library/2019/4/2019horizonreport.pdf?la=en\&hash=C8E8 D444AF372E705FA1BF9D4FF0DD4CC6F0FDD1.

[6] R. Watermeyer, T. Crick, C. Knight, J. Goodall, (2021). "COVID-19 and digital disruption in UK universities: Afflictions and affordances of emergency online migration." High. Educ., 81, pp. 623-641. [Online].

Available: https://link.springer.com/article/10.1007\%2Fs10734-020-00561-y.

[7] J.K. Rowling, Harry Potter and the Philosopher's Stone, 1st ed. Bloomsbury, U.K., ch. 12, 1997.

[8] R. Browning, Andrea del Sarto, 1855.

[9] H. Niemi, P. Kousa, "A Case Study of Students' and Teachers' Perceptions in a Finnish High School during the COVID Pandemic,' International Journal of Technology in Education and Science, vol. 4, pp. 352-369, 2020. 10.46328/ijtes.v4i4.167. pp. 1.

[10] "Latin America and the Caribbean and the COVID-19 pandemic: economic and social effects," ECLAC (Economic Commission for Latin America and the Caribbean Special Report COVID-19, no. 1, Social Panorama of Latin America, 2018 (LC/PUB.2019/3-P), Santiago, 2019.

[11] "Education in the time of COVID-19," ECLAC (Economic Commission for Latin America and the Caribbean), Special Report COVID-19, no. 1, Santiago, April 2020. 
[12] M. Schwartz, "For whom do we write the curriculum?" Journal of Curriculum Studies, vol. 38 , no. 4, pp. 449-457, 2006. Available: https://doi.org/10.1080/00220270500296606.

[13] G. Yazcayir, H. Gurgur, "Students with Special Needs in Digital Classrooms during the COVID-19 Pandemic in Turkey," Pedagogical Research, vol. 6, no. 1 em0088, pp. 1, 2021. Available: https://doi.org/10.29333/pr/9356.

[14] K. Schaeffer, "As schools shift to online learning amid pandemic, here's what we know about disabled students in the U.S," May 2020 Available: https://www.pewresearch.org/fact-tank/2020/04/23/asschools-shift-to-online-learning-amidpandemic-heres-what-we-knowabout-disabled-students-in-the-u-s/.

[15] N. Mustafa, "Impact of the 2019 - 20 coronavirus pandemic on education," International Journal of Health Preference Research, pp. 1-36, 2020.

[16] D. R. Petretto, I. Masala, C. Masala, "Special educational needs, distance learning, inclusion and COVID-19," Education Sciences, vol 10, no. 6, pp. 154, 2020.

[17] R. David, A. Pellini, K. Jordan, T. Phillips, "Education during the COVID-19 crisis- Opportunities and constraints of using EdTech in low-income countries," Policy Brief. EdTechHub. pp. 4, 2020.

[18] A. Andrew, S. Cattan, M. Costa-Dias, C. Farquharson, L. Kraftman, S. Krutikova, A. Phimister, A. Sevilla, "Learning During the Lockdown: Real-Time Data on Children's Experiences During Home Learning," (IFS Briefing Note BN288) The Institute for Fiscal Studies, pp. 20. $2020 \quad$ Available: https://www.ifs.org.uk/uploads/Edited_FinalBN288\%20Learning\%20 during\%20the\%20lockdown.pdf.

[19] K. L. Kritzer, \& C. E. Smith, "Educating deaf and hard-of-hearing students during COVID-19: What parents need to know," The Hearing Journal, vol. 73 , no. 8, pp. 32, 2020. Available: https://doi.org/10.1097/01.HJ.0000695836.90893.20.

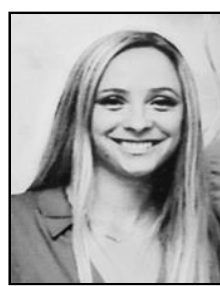

Dušica Karimanović was born in Užice, Serbia, in 1988. She earned a Bachelor of Arts degree in English Language and Literature at the University of Belgrade, Serbia, Faculty of Philology, Department of English Language and Literature, in 2011 with majors in pedagogy and teaching. The following year the author obtained a Master of Arts degree at the same university majoring in language, literature and culture.

Upon completing her studies she instantly started working as a Teacher of English, first in a renowned private language school in her hometown for two years, then in various primary and secondary schools, as well as a local private university. Currently, she is employed at the same position in a school for the disabled in Užice This is her first article. Her current aspirations are teaching English in deprived conditions and a multicultural environment, whereas the research she undergoes is in the domain of teaching English to the deaf and mentally challenged.

Ms Karimanović is a member of ELTA, Association of Scientific and Technical Translators of Serbia, where she obtained a diploma. She also completed a course diploma in Consecutive and Simultaneous Interpreting at Master Translation. 